\title{
ANALISIS KEBUTUHAN MODEL PEMBELAJARAN BERBASIS MULTIKULTURAL PADA MATA PELAJARAN SEJARAH
}

\author{
Ika Rahmatika Chalimi \\ Pendidikan Sejarah FKIP Universitas Tanjungpura \\ Email: ika.rahmatika.chalimi@fkip.untan.ac.id
}

\begin{abstract}
Abstrak
Penelitian ini bertujuan untuk menganalisis kebutuhan model pembelajaran berbasis multikultural melalui analisis studi literatur dan survei lapangan. Penelitian dilakukan dengan pendekatan kualitatif deskriptif. Teknik pengumpulan data menggunakan studi literatur dan wawancara. Teknik analisis data yang digunakan adalah analisis deskriptif. Hasil penelitian menunjukan (1) Studi literatur yang dilakukan meliputi dua hal yaitu analisis kurikulum dengan mengkaji Peraturan Menteri Pendidikan dan Kebudayaan tahun 2016 mengenai kurikulum 2013 untuk mengetahui kebutuhan kurikulum pada mata pelajaran sejarah terkait model pembelajaran dan analisis teoretis dengan mengkaji beberapa literatur mengenai model pembelajaran dan karakteristik mata pelajaran sejarah yang digunakan dalam mendukung pengembangan model pembelajaran berbasis multikultural. (2) Survei lapangan dilakukan melalui wawancara dengan guru mata pelajaran sejarah di Sekolah Menengah Atas Negeri 2, Sekolah Menengah Atas Negeri 8 dan Sekolah Menengah Atas Negeri 9 Kota Pontianak. Pada intinya guru telah melaksanakan pembelajaran berbasis multikultural, tetapi tidak didasari pada pemahaman pelaksanaan pendidikan multikultural. (3) Dirumuskan sintak model pembelajaran berbasis multikultural.
\end{abstract}

Kata Kunci: analisis kebutuhan; model pembelajaran; multikultural; mata pelajaran sejarah;

\begin{abstract}
This research aims to analyze the needs of multicultural based learning through analysis of literature studies and field survey. The research was done with a descriptive qualitative approach. Data collection technique used literature studies and interviews. The data analysis used descriptive analysis. The results of research show: (1) the literature study was done includes two things, curriculum analysis reviewing The Minister of Education and Culture Regulation 2016 about the 2013 curriculum which is done to know the needs of curriculum in historical subjects related to the multicultural based learning model and teorethical analysis reviewing some literature about the model of learning and the characteristics of historical subjects use in support of development multicultural based learning. (2) The field surve y is done by interview history teachers on senior high school 2, senior high school 8 and senior high school 9 of Pontianak. Basically the teachers have done multicultural learning process but they not aware about understanding the implementation of multicultural education (3) The formulation of multicultural based learning syntax.
\end{abstract}

Keywords: needs analysis; based learning; multicultural; historical subjects;

\section{PENDAHULUAN}


Pendidikan merupakan salah satu hal yang terpenting dalam setiap kehidupan manusia, karena pendidikan dapat mengembangkan pola pikir setiap manusia dan masyarakat. Pendidikan merupakan kunci modernisasi atau pendidikan merupakan investasi manusia memperoleh pengakuan dari banyak kalangan ahli (Kunandar, 2007:10). Dalam pernyataan tersebut dapat diartikan bahwa pendidikan mempunyai posisi yang penting karena dapat mempengaruhi pembangunan suatu bangsa.

Sekolah harus mempersiapkan peserta didiknya untuk hidup dalam komunitas masyarakat yang beragam dengan merasakan realitas perbedaan, membantu peserta didik setuju dengan pemahaman dan kepercayaan, menumbuhkan sikap simpati, toleransi, keterbukaan untuk hidup dan berfikir secara berbeda. Sekolah juga harus memperhatikan literasi interkultural, memelihara pemahaman yang baik antara kelompok budaya yang berbeda, dan membantu peserta didik memperoleh kesempatan untuk menyatukan ide-ide dan nilai-nilai (Parekh, 2005:14-15).

Harapannya, dengan implementasi pendidikan yang berwawasan nilai-nilai yang menjunjung tinggi multikultural, akan membantu peserta didik mengerti, menerima dan menghargai orang lain yang berbeda suku, budaya dan nilai kepribadian serta aspek lainnya. Sekolah mempunyai kewenangan untuk mengembangkan kurikulum sesuai dengan kebutuhan, lingkungan dan kondisi sekolah. Sekolah dapat mengintegrasikan nilai-nilai tersebut ke dalam mata pelajaran di sekolah terutama pelajaran sejarah.

Pembelajaran sejarah sebagai unsur pengembangan nasionalisme kultural sangat berfungsi untuk menjadi mediasi dalam memantapkan hubungan antara unsur-unsur masyarakat plural (Supardan, 2009:97). Pembelajaran sejarah di sekolah mengandung dua misi, yaitu 1) sebagai pendidikan intelektual, 2) sebagai pendidikan nilai, pendidikan kemanusiaan, pendidikan pembinaan moralitas, jati diri, nasionalisme dan identitas bangsa (Agung S, 2013:63). Hal ini menjadikan bahwa dalam pembelajaran sejarah menjadi penting ketika menerapkan nilai-nilai multikultural. Seorang guru diharuskan tidak hanya menguasai dan mampu secara 
profesional mengajarkan mata pelajaran sejarah, tetapi juga ia harus mampu menanamkan nilai-nilai multikultural dalam kegiatan belajar mengajar.

Proses pembelajaran yang lebih mengarah pada upaya menghargai perbedaan diantara sesama manusia sehingga terwujud ketenangan dan ketentraman tatanan dalam kehidupan masyarakat. Inti dari pembelajaran sejarah adalah selain bagaimana menanamkan nilai-nilai kepahlawanan, kecintaan terhadap bangsa, jati diri dan budi pekerti kepada peserta didik, melainkan juga menanamkan nilai-nilai multikultural yang akan diterapkan oleh peserta didik dalam kehidupan sehari-hari sehingga aspek metode strategi dan manajemen pembelajaran sejarah merupakan aspek penting dalam penerapan nilai-nilai multikultural.

Faktor utama yang mendorong keberhasilan proses belajar mengajar adalah guru. Untuk itu guru yang bersangkutan hendaknya mampu melaksanakan perannya dengan baik sesuai dengan kurikulum yang berlaku. Seorang guru diharuskan tidak hanya menguasai dan mampu secara profesional mengajarkan mata pelajaran sejarah, tetapi juga ia harus mampu menanamkan nilai-nilai multikultural dalam kegiatan belajar mengajar sehingga diperlukan strategi pembelajaran yang berbasis multikutlural.

Dari aspek metode strategi dan manajemen pembelajaran sejarah merupakan aspek penting dalam penerapan nilai-nilai multikultural. Guru yang memiliki pemahaman terhadap latar belakang budaya peserta didiknya, akan menciptakan lingkungan fisik yang kondusif untuk belajar. Dalam proses pembelajaran guru tidak membedakan gender, suku, ras, etnik dan lain-lain. Dengan strategi pembelajaran sejarah tersebut para peserta didik diasumsikan akan memiliki wawasan dan pemahaman yang mendalam tentang adanya keragaman dalam kehidupan sosial.

Menurut Nafisa Feriana Felid an Syaiful Islam (2019: 167-168) dalam hasil penelitian ini, penerapan pembinaan pendidikan berbasis multikultural terhadap siswa, pihak sekolah khususnya guru-guru yang bersangkutan telah mengembangkan Kurikulum 2013 dalam menyampaikan materi pembelajaran terhadap peserta didik. Guru dengan mudah memperoleh penilaian sikap 
(karakter) siswa dengan menggunakan metode-metode yang beragamdalam menggunakan kurikulum 2013. Karena dalam implementasi pendidikan multikultural peran seorang guru sangat penting terutama sebagai pengembang dan pelaksana pendidikan.

Model rancangan pembelajaran secara umum dapat diartikan sebagai tampilan grafis, suatu kerangka konseptual yang melukiskan aturan yang sistematis dalam mengorganisasikan belajar untuk mencapai tujuan pembelajaran tertentu. Dengan demikian, aktivitas belajar mengajar benar-benar merupakan kegiatan yang tertata secara sistematis dan terlaksana sesuai dengan yang telah direncanakan (Prawiradilaga, 2007:33).

Model pembelajaran sendiri bukannya tanpa pilihan. Model pembelajaran mempunyai banyak bentuk dan pilihan sesuai dengan kebutuhan yang dirasakan guru. Model pembelajaran dijadikan sebagai gaya guru dalam melakukan pembelajaran di kelas. Hal terpenting dalam penggunaan model pembelajaran adalah tercapainya tujuan pendidikan secara efektif dan efisien.

Menurut Farida Hanum dan Sisca Rahmadonna (2013:41) menyatakan bahwa hasil dari penelitian untuk meningkatkan apresiasi-apresiasi yang bersifat positif kepada diri peserta didik terhadap perbedaan secara kebiasaan dan kebudayaan, sebagai landasan untuk meningkatkan kualitas pembelajaran yang memberikan rasa aman, nyaman, dan suasana kondusif bagi peserta didik selama belajar di sekolah agar pembelajaran tersebut menjadi efektif dan efesien. Pembelajaran multikultural tidak diberikan secara tersendiri di dalam kelas, namun dapat diintegrasikan pada berbagai macam mata pelajaran. Model pembelajaran multikultural diberikan dengan memakai modul, sehingga modul pembelajaran pendidikan multikultural berfungsi sebagai suplemen (tambahan) materi pelajaran.

Sejalan dengan permasalahan di atas, maka tujuan penelitian ini adalah untuk mendeskripsikan analisis kebutuhan pada studi literatur dalam mengembangkan model pembelajaran berbasis multikultural pada mata pelajaran sejarah di SMAN Kota Pontianak, (2) analisis kebutuhan pada survei lapangan dalam mengembangkan model pembelajaran berbasis multikultural pada mata 
pelajaran sejarah di SMAN Kota Pontianak, (3) draft pengembangan bentuk sintak model pembelajaran berbasis multikultural pada mata pelajaran sejarah di SMAN Kota Pontianak. Sejak dini peserta didik harus diberikan kesadaran kontekstual mengenai ruang publik tempat dimana mereka bertempat tinggal, bergaul, berinteraksi dan berkehidupan. Bahwa mereka juga merupakan subjek yang mempengaruhi dan dapat memberi kontribusi bagi terciptanya ruang publik mereka menjadi lebih baik.

Pada dasarnya model-model pembelajaran yang berkaitan dengan kebangsaan memang sudah ada. Namun, hal itu masih kurang memadai sebagai sarana pendidikan guna menghargai perbedaan masing-masing suku, budaya, dan etnis. Untuk dapat mengembangkan model pembelajaran berbasis multikultural dalam pembelajaran sejarah, maka perlu kiranya dilakukan penelitian agar diperoleh produk model pembelajaran sejarah yang dapat menanamkan nilai-nilai multikultural.

\section{METODE}

Penelitian dilakukan dengan pendekatan penelitian kualitatif deskriptif. Kehadiran peneliti dalam penelitian yaitu survei berbagai literatur dan wawancara dengan guru terkait dengan analisis kebutuhan model pembelajaran. Lokasi penelitian yang digunakan untuk mengumpulkan data penelitian melalui wawancara guru sejarah yaitu a) SMAN 2 Pontianak, wawancara dilakukan dengan ibu Yashinta, S.Pd yang memiliki masa kerja kurang lebih 20 tahun, b) SMAN 8 Pontianak, wawancara dilakukan dengan ibu Diah Retno Lestari, S.Pd yang memiliki masa kerja kurang lebih 10 tahun, dan c) SMAN 9 Pontianak, wawancara dilakukan dengan ibu Anjar Kuswandari, S.Pd yang memiliki masa kerja kurang lebih 10 tahun. Sedangkan pencarian literatur yang digunakan dalam penelitian yaitu literatur yang berada di perpustakaan Untan, perpustakaan IKIP PGRI Pontianak, perpustakaan kota Pontianak dan perpustakaan daerah Kalimantan Barat. Teknik pengumpulan data menggunakan studi literatur (dokumen) dan wawancara. Teknik analisis data yang digunakan adalah analisis 
deskriptif dengan reduksi data, penyajian data, penarikan kesimpulan dan verifikasi.

\section{HASIL DAN PEMBAHASAN}

\section{Analisis Kebutuhan Pengembangan Model Pembelajaran Berbasis Multikultural dengan Studi Literatur}

Studi literatur yang dilakukan pada penelitian ini dilakukan dengan cara pencarian literatur terkait dengan pengembangan model pembelajaran sejarah berbasis multikultural. Studi literatur dilakukan oleh peneliti dengan tujuan utama yaitu mencari dasar pijakan atau fondasi untuk memperoleh dan membangun landasan teori, kerangka berpikir, dan menentukan dugaan sementara atau disebut juga dengan hipotesis penelitian. Sehingga peneliti dapat menggelompokkan, mengalokasikan, mengorganisasikan, dan menggunakan variasi pustaka dalam bidangnya. Dengan melakukan studi literatur, peneliti mempunyai pendalaman yang lebih luas dan mendalam terhadap masalah yang hendak diteliti.

Faktor-faktor yang dipandang penting untuk dianalisis dan dipertimbangkan dalam pengembangan model pembelajaran berbasis multikultural salah satunya adalah studi literatur. Dalam studi literatur, analisis kurikulum dan analisis referensi terkait dengan pengembangan model pembelajaran berbasis multikultural dilakukan untuk menentukan kebutuhan model yang bisa digunakan dalam proses pembelajaran sehingga model yang dikembangkan dapat disesuaikan dengan kondisi di lapangan.

Studi literatur dalam analisis kebutuhan ini merupakan langkah awal yang harus dilakukan dalam pengembangan model pembelajaran berbasis multikultural. Dwiyogo (2001:1) mengemukakan tiga hal penting yang harus dilakukan dalam penelitian pengembangan yaitu menganalisis kebutuhan, mengembangkan produk dan menguji coba produk. Analisis tersebut dimaksudkan untuk mengetahui kebutuhan apa saja yang diperlukan guna mengatasi masalah yang ditemui dalam kegiatan pembelajaran. Dengan demikian diharapkan produk yang dihasilkan benar-benar produk yang sesuai dnegan kebutuhan (based on need). 
Studi literatur yang pertama dilakukan adalah analisis kurikulum. Analisis kurikulum dilakukan agar model pembelajaran yang dikembangkan sesuai dengan kurikulum yang berlaku pada saat ini. Hal ini bertujuan agar model pembelajaran bisa digunakan pada kegiatan pembelajaran di sekolah. Analisis kurikulum yang digunakan yaitu analisis Permendikbud tahun 2016. Ada 5 item yang dianalisis dalam peraturan tersebut yaitu Permendikbud tahun 2016 no 20, 21, 22, 23 dan 24.

Studi literatur kedua dalam penelitian adalah analisis referensi. Analisis referensi ini dilakukan dengan mencari dan mengkaji referensi-referensi yang dapat mendukung pengembangan model pembelajaran berbasis mutikultural. Penelusuran referensi dilakukan di perpustakaan daerah, perpustakaan kota Pontianak dan perpustakan Universitas Tanjungpura. Lama penelusuran referensi juga disesuaikan dengan ketersediaan data yang dibutuhkan. Harapannya setelah data dari referensi dikatakan sesuai dengan kebutuhan, model pembelajaran dapat dikembangkan sesuai dengan kebutuhan di lapangan.

Referensi yang digunakan adalah referensi yang mendukung model pembelajaran berbasis multikultural dan karakteristik pembelajaran sejarah. Hal ini diupayakan agar model pembelajaran multikultural dapat membantu guru dalam mengelola proses pembelajaran menjadi lebih efisien dan efektif, terutama memberikan kemampuan peserta didik dalam membangun kolaboratif dan memiliki komitmen nilai yang tinggi dalam kehidupan masyarakat yang serba majemuk. Adapun beberapa faktor yang menjadi pertimbangan dalam mengembangkan model pembelajaran berbasis multikultural adalah sebagai berikut (a) tuntutan kompetensi mata pelajaran yang harus dibekalkan kepada peserta didik berupa pengetahuan (knowledge), keterampilan (skills), dan etika atau karakter (ethic atau disposition), (b) tuntutan belajar dan pembelajaran, terutama terfokus membuat orang untuk belajar dan menjadikan kegiatan belajar adalah proses kehidupan, (c) kompetensi guru dalam menerapkan pendekatan multikultural, (d) analisis terhadap latar kondisi peserta didik.

Dalam penelitian ini, pemilihan strategi dilakukan dengan cara analisis secara mendalam guna mendapatkan model pembelajaran sesuai dengan yang 
diharapkan. Dari hasil analisis, strategi cooperative learning menjadi pilihan dalam mengembangkan model pembelajaran berbasis multikultural. Hal ini didasarkan bahwa dengan strategi cooperative learning dapat digunakan untuk menandai adanya perkembangan kemampuan peserta didik dalam belajar bersama-sama mensosialisasikan konsep dan nilai budaya lokal dari daerahnya dalam komunitas belajar bersama teman. Dalam tataran belajar dengan pendekatan multikultural, penggunaan strategi cooperative learning, diharapkan mampu meningkatkan kadar partisipasi peserta didik dalam melakukan rekomendasi nilai-nilai lokal serta membangun cara pandang kebangsaan.

Kriteria yang dapat digunakan untuk mengetahui keberhasilan kegiatan belajar peserta didik adalah laporan kerja (makalah), unjuk kerja dan partisipasi yang ditampilkan oleh peserta didik dalam pembelajaran dengan cara diskusi dan curah pendapat. Selain itu, kriteria lain yang dapat digunakan adalah unjuk kerja yang ditampilkan oleh guru di dalam melaksanakan pendekatan multikultural dalam pembelajarannya. Guru yang bersangkutan selalu terlibat dalam setiap fase kegiatan pembelajaran, baik dalam kegiatan diskusi dan refleksi hasil temuan awal, penyusunan rencana tindakan, pelaksanaan tindakan, pengamatan dalam pelaksanaan tindakan, diskusi dan refleksi hasil pelaksanaan tindakan, dan penentuan/penyusunan rencana tindakan selanjutnya dalam pencapaian tujuan pembelajaran. Sesuai dengan karakteristik pembelajaran sejarah, maka idealnya pembelajaran sejarah disajikan dengan strategi yang menantang peserta didik.

\section{Analisis Kebutuhan Pengembangan Model Pembelajaran Berbasis Multikultural dengan Survei Lapangan}

Survei lapangan dilakukan melalui wawancara dengan guru mata pelajaran sejarah di SMAN 2, SMAN 8 dan SMAN 9 Kota Pontianak. Survei lapangan bertujuan untuk memperoleh data mengenai kebutuhan yang diinginkan dalam penelitian. Diharapkan dengan survei lapangan, pengembangan produk model pembelajaran berbasis multikultural sesuai dengan kebutuhan penelitian sehingga dapat dimanfaatkan dalam kegiatan pembelajaran. 
Di SMAN 2 Pontianak, persiapan secara khusus saat guru akan mengajar dikelas dengan peserta didik yang beragam yaitu dalam menerapkan metode yang digunakan, guru masih terkendala pada materi yang akan disampaikan, dimana para peserta didik masih asing dengan materi yang baru mereka dapatkan namun guru dapat menyampaikan materi dengan baik kepada peserta didik. Dalam melakukan evaluasi dikelas guru menggunakan kriteria penilaian melalui keaktifan peserta didik saat presentasi atau bertanya saat diberi kesempatan untuk bertanya.

Warga sekolah di Di SMAN 8 Pontianak dapat dikatakan beragam. Baik dari suku, agama, ras, maupun golongan. Hal ini membuat interaksi di sekolah heterogen, baik antar guru, antar peserta didik, maupun antara guru dan peserta didik atau sebaliknya. Interaksi antara guru dan peserta didik di sekolah, guru menilai cukup baik. Sampai saat ini, seperti yang diamati, tidak ada kendala yang berarti. Setiap akan menyampaikan pembelajaran di dalam kelas, guru selalu melakukan persiapan. Utamanya yang dibuat perangkat pembelajaran berupa Rencana Pelaksanaan Pembelajaran atau RPP. Di dalam proses pembelajaran, guru sering menggunakan model pembelajaran diskusi, quantum learning, dan powerpoint sebagai media pembelajaran. Kadang guru juga menyelipkan games agar peserta didik tidak bosan. Dalam proses pembelajaran, pasti ada karakterkarakter yang ingin dimunculkan. Untuk karakter yang ingin dimunculkan dalam pembelajaran sebagai bekal untuk kehidupan sehari-hari adalah kejujuran.

Di SMAN 9 Pontianak, selama mengajar di kelas, guru merasakan ada kendala dalam menghadapi peserta didik yang beragam. Namun kendala tersebut bukan dari keberagaman suku, agama, ras, maupun golongan yang perlu perlakuan yang berbeda. Kendala dirasakan oleh guru tersebut lebih kepada cara menghadapi peserta didik yang kenakalannya sulit diatasi. Perencanaan pembelajaran yang biasa disiapkan oleh guru di SMAN 9 Pontianak, khususnya mata pelajaran sejarah adalah perangkat pembelajaran seperti Silabus dan RPP. Selain itu, ada hal khusus yang dipersiapkan guru sejarah yaitu metode yang digunakan untuk menghadapi kondisi peserta didik yang beragam di dalam kelas. Dalam proses pembelajaran, guru biasanya menggunakan Discovery Learning, 
Project Based Learning, Problem Based Learning. Langkah-langkah yang digunakan disesuaikan dengan model yang digunakan pada saat proses belajar mengajar. Pada saat proses pembelajaran di kelas, tanggapan peserta didik sangat beragam. Karakter yang ingin dimunculkan dalam pembelajaran sejarah di SMAN 9 Pontianak disesuaikan dengan Penguatan Pendidikan Karakter (PPK) yang ada di Kurikulum 2013 seperti sikap nasionalisme.

Sebagian besar guru belum memahami konsep pendidikan multikultural. Guru sadar maupun tidak, pada intinya telah melaksanakan pembelajaran berbasis multikultural, tetapi tidak didasari pemahaman tentang bagaimana seharusnya pendidikan multikultural itu diimplementasikan dalam proses pembelajaran. Guru harus dapat mengenal dan mengakui perbedaan kebudayaan dalam membuat kurikulum baru dengan melihat kenyataan nilai-nilai yang terdapat pada keragaman masyarakat. Guru harus mengetahui latar belakang budaya para peserta didiknya masing-masing. Hal ini dikemukakan oleh Hickling-Hudson (2004:271) yaitu guru dan peserta didik membutuhkan keterampilan utama dalam mengatasi konflik antar etnis dan mencapai hubungan harmoni sosial sehingga dapat meminimalisir terjadinya masalah-masalah sosial.

Center for Multicultural Education (2001:6) juga mengemukakan hal yang sama mengenai kemampuan guru dalam mengetahui latar belakang budaya peserta didik. Guru harus mempunyai pengetahuan yang luas mengenai latar belakang perbedaan budaya peserta didiknya. Guru harus respon terhadap peserta didik berbeda ras, etnis, budaya dan bahasa. Sejak dini guru harus memberikan peserta didik kesadaran kontekstual mengenai ruang publik tempat dimana mereka bertempat tinggal, bergaul, berinteraksi dan berkehidupan. Bahwa mereka juga merupakan subjek yang mempengaruhi dan dapat memberi kontribusi bagi terciptanya ruang publik mereka menjadi lebih baik.

\section{Draft Model Pembelajaran Berbasis Multikultural Pada Mata Pelajaran Sejarah}

Guru yang kreatif dan profesional dapat menciptakan ide-ide dalam merancang sistem pembelajaran baru yang mampu membuat peserta didik untuk 
mencapai tujuan belajarnya dengan penuh rasa puas. Pengembangan model pembelajaran berbasis multikultural bertujuan agar dalam pelaksanaan pembelajaran peserta didik tidak hanya mendapatkan materi saja, namun setelah selesai pembelajaran ada makna yang dapat diperoleh peserta didik yaitu mengenai wawasan multikultural. Dari hasil analisis kebutuhan dapat dirumuskan draft kasar model pembelajaran berbasis multikultural dengan langkah-langkah sebagai berikut:

1) Guru memberikan penjelasan sekilas mengenai materi pelajaran. Hal ini bertujuan memberikan kesempatan kepada peserta didik untuk dapat mengeksplorasi kemampuan mereka dalam memahami materi dan tidak membatasi cara pandang peserta didik terhadap materi.

2) Guru memberikan kebebasan kepada peserta didik dalam memilih kelompok belajar. Hal ini dilakukan agar peserta didik mampu untuk mengenal karakteristik dari masing-masing temannya.

3) Guru memberikan kebebasan kepada peserta didik untuk menyampaikan pendapat. Hal ini dilakukan agar peserta didik merasa memiliki kebebasan untuk menyampaikan pendapat masing-masing dan mereka tidak merasa bahwa guru membatasi pendapat mereka.

4) Guru mempersilahkan peserta didik untuk bertanya mengenai materi. Hal ini bertujuan memberikan penguatan pemahaman kepada peserta didik mengenai materi.

5) Guru mengarahkan peserta didik untuk dapat melakukan evaluasi sendiri, baik terhadap pemahaman materi maupun pengalaman dalam mempelajari materi. Hal ini terkait dengan pencapaian ranah kompetensi sikap, pengetahuan dan keterampilan dalam kegiatan pembelajaran. 
Guru memberikan penjelasan sekilas mengenai materi pelajaran. Hal ini bertujuan memberikan kesempatan kepada peserta didik untuk dapat mengeksplorasi kemampuan mereka dalam memahami materi dan tidak membatasi cara pandang peserta didik terhadap materi.

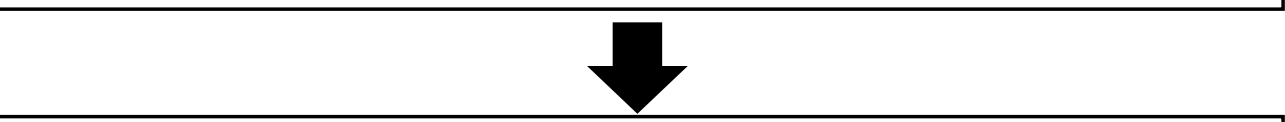

Guru memberikan kebebasan kepada peserta didik dalam memilih kelompok belajar.

Hal ini dilakukan agar peserta didik mampu untuk mengenal karakteristik dari masing-masing temannya.

\section{Guru memberikan kebebasan kepada peserta didik untuk menyampaikan pendapat.}

Hal ini dilakukan agar peserta didik merasa memiliki kebebasan untuk menyampaikan pendapat masing-masing dan mereka tidak merasa bahwa guru membatasi pendapat mereka.

\begin{tabular}{|c|}
\hline Guru mempersilahkan peserta didik untuk bertanya mengenai \\
materi. \\
Hal ini bertujuan memberikan penguatan pemahaman kepada peserta \\
didik mengenai materi.
\end{tabular}

Gambar 1. Sintak Model Pembelajaran Berbasis Multikultural 


\section{SIMPULAN}

Dari hasil penelitian, dapat disimpulkan sebagai berikut:

1. Pembelajaran sejarah berbasis multikultural di sekolah memberikan kewenangan lebih luas untuk menyusun dan mengembangkan kurikulum sekolah sesuai kondisi dan kebutuhan sekolah dan para peserta didik berada. Karena sekolah dianggap yang paling tahu tentang kondisi, kebutuhan dan harapan para peserta didiknya dan dalam rangka menanamkan nilai multikultural.

2. Analisis kebutuhan melalui studi literatur dan survei lapangan menjadi studi pendahuluan dalam mengembangkan model pembelajaran berbasis multikultural. Hal ini dilakukan agar model pembelajaran yang dikembangkan sesuai dengan kebutuhan terkait dengan keragaman yang ada di sekolah sehingga dapat meminimalisir konflik yang terjadi di sekolah.

3. Draft model pembelajaran berbasis multikultural dikembangkan sesuai dengan hasil analisis kebutuhan. Pengembangan model pembelajaran berbasis multikultural bertujuan agar dalam pelaksanaan pembelajaran peserta didik tidak hanya mendapatkan materi saja, namun setelah selesai pembelajaran ada makna yang dapat diperoleh peserta didik yaitu mengenai wawasan multikultural.

\section{UCAPAN TERIMAKASIH}

Dengan adanya penelitian ini, peneliti mengucapkan terima kasih kepada pihak yang telah membantu dan berkontribusi banyak sehingga dapat terselesaikan dengan baik antara lain Kepala Sekolah Menegah Atas Negeri 2 dan guru sejarah, Kepala Sekolah Menengah Atas Negeri 8 dan guru sejarah dan Kepala Sekolah Menengah Atas Negeri 9 dan guru sejarah yang telah mengijinkan dalam pencarian data. Tak lupa, terima kasih kepada anggota penelitian yang rela menghabiskan waktunya untuk mengumpulkan dan menganalisis data sehingga laporan penelitian dapat diselesaikan pada masa tenggat waktunya.

\section{DAFTAR PUSTAKA}


Agung S. L dan Sri Wahyuni. 2013. Perencanaan Pembelajaran Sejarah. Yogyakarta: Penerbit Ombak.

Departemen Pendidikan Nasional. 2006. Peraturan Menteri Pendidikan Nasional Republik Indonesia Nomor 22 Tahun 2006 Tentang Standar Isi. Jakarta: Departemen Pendidikan Nasional.

2016. Peraturan Menteri Pendidikan dan Kebudayaan Tahun 2016 No 20 Tentang Standar Kompetensi Lulusan. Jakarta: Departemen Pendidikan Nasional.

2016. Peraturan Menteri Pendidikan dan Kebudayaan Tahun 2016 No

21 Tentang Standar Isi. Jakarta: Departemen Pendidikan Nasional.

2016. Peraturan Menteri Pendidikan dan Kebudayaan Tahun 2016 No

22 Tentang Standar Proses. Jakarta: Departemen Pendidikan Nasional.

2016. Peraturan Menteri Pendidikan dan Kebudayaan Tahun 2016 No

23 Tentang Standar Penilaian. Jakarta: Departemen Pendidikan Nasional.

2016. Peraturan Menteri Pendidikan dan Kebudayaan Tahun 2016 No

24 Tentang Kompetensi Inti dan Kompetensi Dasar. Jakarta: Departemen Pendidikan Nasional.

Center for Multicultural Education. 2001. Diversity Within Unity: Essential Principles for Teaching and Learning in a Multicultural Society. Seattle: College of Education University of Washington.

Feli, Nafisa Feriana dan Syaiful Islam. 2019. Implementasi Multicultural Based Learning dalam Meningkatkan Prestasi Siswa. Jurnal Mudarrisuna, Vol.3 No.1.

Dwiyogo, Wasis D. 2014. Konsep Penelitian dan Pengembangan. Malang: Pusat Kajian Kebijakan Olahraga LEMLIT UM.

Hanum, Farida dan Setya Raharja. 213. Pengembangan Model Pembelajaran Multikultural Terintegrasi Mata Pelajaran IPS di Sekolah Dasar. Jurnal Penelitian Ilmu Pendidikan, Vol. 6 No.2.

Hickling-Hudson, A. 2004. Educating Teachers for Cultural Diversity and Social Justice. pp 270-307. dalam G.Hernes (ed.) with M. Martin, Planning For Diversity: Education in Multi-Ethnic and Multicultural Societies. International Institute for Education Planning (UNESCO), Paris.

Kunandar. 2007. Guru Profesional (revisi 2014). Jakarta: Rajawali Pers. 
Parekh, B. 2005. Unity and Diversity in Multicultural Societies. Geneva: International Labour Organization (International Institute for Labour Studies).

Prawiradilaga, Dewi Salma. 2007. Prinsip Desain Pembelajaran. Jakarta: Reneka. Cipta.

Supardan, D dan A. Razak Ahamad. 2009. Pembelajaran Sejarah Berbasis Pendekatan Multikultural dan Perspektif Sejarah Lokal, Nasional Global untuk Integrasi Bangsa (Studi Kasus Eksperimental Terhadap Peserta didik Sekolah Menengah Umum di Kota Bandung. Jurnal Forum Kependidikan, Vol. 28 No. 2. 